\title{
残余利益オプションモデルによる インターネット企業の株式評価 Stock Valuation of Internet Company based on Residual Income Option Model
}

\author{
佐藤 清和 1 \\ （金沢大学 人間社会研究域）
}

Kiyokazu Sato

Institute of Human and Social Sciences, Kanazawa University

\begin{abstract}
Summary: Stocks are securities embedding two contingent clams consisted of residual assets and dividend distribution. These claims yield a future pay-off replicated as real option for stockholders. Accountability in corporate accounting represents the responsibility of reporting the useful information to evaluate these two clams. It follows that firms' managers ultimately execute their accountabilities by reporting the real option value included in stocks. This paper indicates that some stock valuation models are derived by double account system supporting this execution of accountability. On that basis, we demonstrate the characteristics of these valuation models by illustrating internet business company faced a heightened risk. Superiority of residual income option model is inferred by Monte-Carlo simulation and sensitivity analysis.
\end{abstract}

キーワード : バリュエーション、残余利益モデル、オールソンモデル、アカウンタビリティー

\section{1.はじめに}

企業会計には、情報利用者の意思決定に有用な会計 情報を伝達する役割とともに、委託財産の運用状態に 関する会計報告を実行する責務が課されている2。後者 の責務とは、委託財産として拠出された資本の運用状 態に関する会計報告責任を意味するアカウンタビリ ティーとして履行される。

経営者（会計担当者）に課されたアカウンタビリテ ィーという責務は、資本の運用状態を継続的に記録し、 これを組織的に集計した上で、最終的に財務表に表示 するという一連の会計処理が、複式簿記に基づいて実 行されることよって自律的に解除される。

本稿は、このようなアカウンタビリティーを前提と する会計情報に基づく株式価值評価モデルである残 余利益モデル(Residual Income Model: RIM) を取り上 げ、つぎの 2 点について検討する。

（1）RIM とは、株式に化体された条件付請求権を評 価するリアルオプションモデルと解されること。

(2) リアルオプションモデルとしての RIM により インターネット企業の株式価值を評価すること。

1 E-mail : kiyosato@staff.kanazawa-u.ac.jp

2 本稿における企業会計とは、営利事業を行う株式会社形

態の企業で実践される会計実務を意味している。

3 拠出資本の運用情報の伝達のみでアカウンタビリティ

一が解除されるわけではない。これはキャッシュ・フロー
なお、本稿において株式価值とは、株式に化体され た残余財産請求権および利益配当請求権という $2 つ 0$ 条件付請求権の価值として定義される。これらの条件 付請求権に基づいて株主に分配される残余財産およ び利益配当とは、企業の資産および資本を原資産とす るリアルオプションからのペイオフとみなされる。し たがって、株主に対するアカウンタビリティーとは、 株式が内包するこれらのリアルオプション価值に関 する会計報告責任ということが可能である3。

本稿では、このような問題意識の下で次のような 3 つの株式価值評価モデルについて検討していく。

(1) 残余財産オプションモデル (2 節)

(2) 残余利益オプションモデル (3 節)

(3) Schwartz and Moon モデル (4 節)

その上で、わが国のインターネット企業を取り上げ、 その株式価值を(2)および(3)のオプションモデルに基 づくシミュレーションによって評価する。

本稿でインターネット企業を取り上げるのは、同業 界が市場の急速な拡大に伴う取引額の増大や、新規企 業の頻繁な参入退出といった需給両面における大き

計算書が制度化されていることからも明らかである。一方 で現行のキャッシュ・フロー計算書が、複式簿記による会 計記録から誘導的かつ直接的には作成されないという問 題は未だ解決されておらず、引き続き検討を要する理論的 課題である (佐藤・佐藤 $[2000])$ 。 
な不確実性に晒されており、このような不確実性に伴 うオプション価值が、株式価值の評価額に含まれると 期待されるからである。

シミュレーションによれば、株式時価総額を基準と して、残余利益オプションモデルの方が Schwartz and Moon モデルより高い評価精度を示すという結果が 得られた。

本稿の構成は、以下のとおりである。次節では、Black and Sholes (1973)で指摘された株式のオプション的性 質について、企業会計の基本等式を用いて検討する。 3 節では、Edwards and Bell (1961) および Ohlson (1995) によって示された残余利益モデルが、リアルオプショ ンモデルの一つと解されることを示す。 4 節では、 Schwartz and Moon (2000)を取り上げ、その計算構造を 3 節の残余利益オプションモデルと比較する。5 節は インターネット企業 R 社の株式価值をモンテカルロ・ シミュレーションによって評価し感度分析を行う。最 後の 6 節は、本稿の問題点と今後の課題である。

\section{2. リアルオプションとしての株式}

企業会計の記録対象となる経済事象は、「資産」、「負 債」および「資本」という3つの取引要素に分類され 会計帳簿に記録される。このように分類された取引情 報は、当期末 $t$ において次式のような「貸借対照表等 式」に従って財務表に集計される。

$$
\text { 資産 }_{t} \equiv \text { 負債 }_{t}+\text { 資本 }_{t}
$$

同式の右辺は資金の調達源泉を示し、また左辺は資 金の運用状態を示す4。図表 1 の上段は、(1)式よる貸 借対照表の例である。ここでは、資本金 75 と利益 45 の資本、ならびに流動負債 10 と長期負債 40 の負債で 調達された資金が、流動資産 90 および固定資産 80 で 運用されていることが表示されている。
4 「資金」とは、希少価值を有する経済財（通貨を含む）を 意味しており、経済学でいう「資本」あるいは会計学の「企 業資本」と同義である。ただし、貸借対照表等式における資 本との混同を回避するため、「資金」という言葉を用いてい
貸 借 対照表

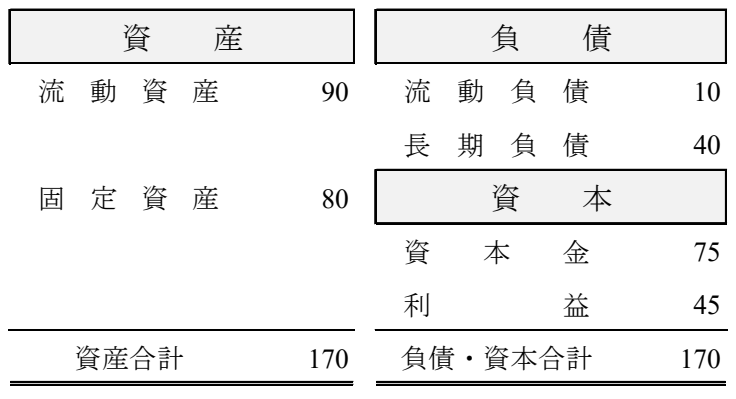

損益計算書

\begin{tabular}{|c|c|c|c|c|}
\hline 費 & & \multicolumn{3}{|c|}{ 益 } \\
\hline 売 上 原 価 & 20 & 売 & 上 & 70 \\
\hline その他費用 & 5 & & & \\
\hline 利 & 45 & & & \\
\hline 費用 • 利益合計 & 70 & 収益合計 & & 70 \\
\hline
\end{tabular}

図表 1 財務諸表の数值例

このように債権者への返済を要する負債および出 資者から委託された資本を源泉とする資金が企業活 動に投下され、その運用結果である資本増分が利益と して、同図表の下段にある損益計算書に表示されるこ とになる。

経営者には、このような株主から拠出された資本の 変動状況に関する報告責任としてのアカウンタビリ ティーが課せられている。この点を明確にするため、 (1)式を次式の「資本等式」に変形する。

$$
\text { 資産 }{ }_{t}-\text { 負債 }_{t} \equiv \text { 資本 }_{t}
$$

ここでは、左辺における資産と負債の差額である正 味財産として右辺の資本が定義されている。これより 将来時点 $T_{L}$ における株式保有によるぺイオフは、次式 のように表わされる5。

$$
\tilde{V}_{T_{L}}=\operatorname{Max}\left[\text { 資産 }_{T_{L}} \text { - 負債 } T_{L}, 0\right]
$$

ここで、左辺の $\tilde{V}_{T_{L}}$ は時点 $T_{L}$ における株式価值であり、 右辺の資産は市場価值を表す確率変数で与えられて いる。また負債は、同時点を満期とする負債額面を表 している。

(3)式のとおり、右辺の正味財産が正の值をとる場合、 正味財産としての資本と株式価值は一致する。しかし ながら、正味財産の值が負の值をとるような債務超過 の場合、株式価值はゼロになる。すなわち、(3)式は資

る $[$ 杉本 $(1991)]$ 。

5 本稿では、会計等式から株式価值評価モデルが導かれるこ とを明瞭に示すために、資産、負債、資本等の取引要素を記 号化せず、これらの用語のまま定式化している。 
産の市場価值を原資産、また返済すべき負債額を行使 価格とするユーロピアン・コールオプションからの満 期ペイオフを表している6。

図表 2 では、(2)式のように資産と負債の差額で与え られる正味財産が、株主の残余財産請求権に基づく請 求対象であることを示している。これは、図表 1 の貸 借対照表を変形し、左側に資産および負債を上下に配 置して、両者の差額（資産の変動額を+一の符号およ び負債の変動額をー+の符号で表した両者の合計）か ら正味財産が得られることを示すものである。

一方、同図表の右側には正味財産に対する分配請求 権を意味する資本が、収益および費用の発生にともな って利益として増加し、これが資本全体の増分として 報告されることにより、アカウンタビリティーが履行 されることが示されている。

以上の関係から、株主の時点 $T_{L}$ における残余財産

（Residual Assets: RA）に対する請求権としての株式価 值は、次式のように与えられる。

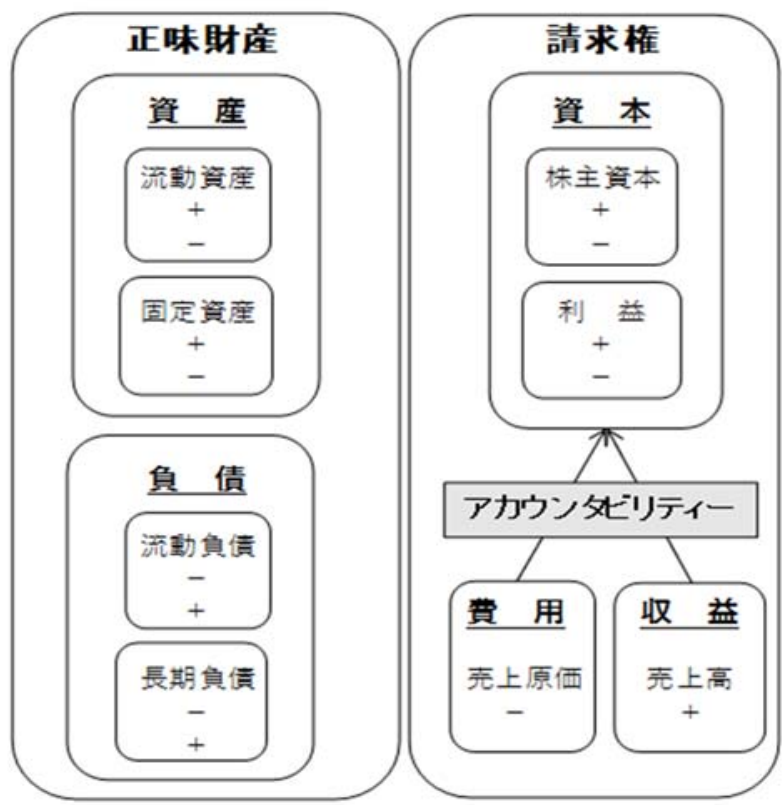

図表 2 正味財産等式とアカウンタビリティー

$$
V_{t}^{R A}=e^{-r_{F}\left(T_{L}-t\right)} E_{t}^{Q}\left(\operatorname{Max}\left[\text { 資産 }_{T_{L}} \text { 一負債 } T_{L}, 0\right]\right)
$$

ここで、 $V_{t}^{R A}$ は残余財産請求権としての株式価值、 $r_{F}$ はリスクフリーレート、また $E_{t}^{Q}[\bullet]$ は時点 $t$ におけるリ スク中立確率測度の下での期待值オペレターである。

6 ここでは、利払い日における企業の倒産は考慮していない。 7 先行研究において、(4)式のオプションモデルは企業の倒 産確率を推定するリスク管理モデルの一つとして研究され ている。詳細については、森平(2007)を参照されたい。 8 Merton(1974)では、株式と単一クラスのゼロクーポン債と いう 2 つのクラスの請求権によって企業資本が構成される として、株式価值がモデル化されている。その発展的かつ現
(4)式のオプションは、残余財産としての実物資産を 原資産とするリアルオプションであるから、本稿では これを「残余財産オプションモデル（Residual Assets Option model: RAO モデル)」と呼ぶこととする7。

ただし、このオプションモデルによって株式価值を 評価することは困難である。なぜなら、金融商品や不 動産以外の諸資産については、一般に取引市場が存在 せず、資産ごとに逐一その価值変動をモデル化するこ とは困難だからである。権利行使価格としての負債に ついても同じことが言える。

周知のとおり、上述のコールオプションは、Black and Scholes (1973)によって指摘されたものであるが、 株式を原資産とする株式オプションの価格モデルを 確立した同論文において、原資産である株式それ自体 がオプション価值を有すると指摘されていることは 大変興味深い。なぜなら、彼らは株式オプションの評 価について検討する過程で、その原資産である株式そ のものが、企業資産を原資産とするリアルオプション として定式化される、ということを指摘しているから であり、したがって、アカウンタビリティーとはこの ような株式のリアルオプション価值を報告対象とす る会計報告責任と言い得るからである8。

\section{3. 残余利益に基づく株式価値評価モデル \\ 3.1 期間損益計算と配当割引モデル}

以下では、現在の時点 $t$ を当期末 (翌期首)，また時 点 $t+1$ を翌期末と定義する。前述のように、株主から 委託された資本の変動要因を明らかにするアカウン タビリティーが履行されるには、図表 2 の右下にある 収益および費用という取引要素を導入し、次式のよう な期間損益計算を必要とする。

$$
\text { 収益 }{ }_{t}-\text { 費用 }_{t} \equiv \text { 利益 }_{t}\left(=\Delta \text { 資本 }_{t}\right)
$$

(5)式は、収益と費用の差額で定義された利益が、当 期末 $t$ の資本増分 $\left(\Delta\right.$ 資本 $\left._{t}\right)$ であることを示している。 ここで、(2)式の資本 $t_{t}$ (5)式の資本の増分を加えるこ とにより、次式のとおり翌期末 $t+1$ の正味財産が得ら れる9。

$$
\begin{aligned}
& \text { 資産 }_{t+1} \text { 一負債 }{ }_{t+1}=\text { 資本 }_{t}+\Delta \text { 資本 }_{t+1} \\
& =\text { 資本 }_{t}+\text { 利益 }_{t+1} \\
& =\text { 資本 }_{t}+\left(\text { 収益 }{ }_{t+1} \text { 一費用 }{ }_{t+1}\right)
\end{aligned}
$$

(6)右辺の 1 式および 2 式は、翌期末の正味財産が、

実的応用については、本機関誌の中岡(2016)を参照されたい。 9 収益および費用とは, 資本という取引要素の変動理由を示 寸特殊な機能 (利潤計算機能) を付与された取引要素の集合 であり、その性質は資本変動の代理変数としての「代位勘定」 であるという点で、資産、負債、資本という取引要素とは異 質だと考えられる（杉本［1997]）。 
当期末 $t$ の資本と翌期末 $t+1$ の資本の増分（すなわち 利益）からなることを示している。また 3 式は、この ような資本増分は、資本の増加要因である収益ないし その減少要因である費用の差額として与えられるこ とを示している。

ここで、以上の期間損益計算によって把握された資 本変動 (利益) のうち、株主へのリターンとして実際 に分配される価值総額に基づく株式価值評価モデル として、次式のような配当割引モデル（Discounted Dividends Model: DDM）を考える。

$$
\left.V_{t}^{D D M}=\sum_{\tau=1}^{\infty} \frac{1}{\left(1+r_{F}\right)^{\tau}} E_{t}^{Q}\left[d \text { 収益 }_{t+\tau}-\text { 費用 }_{t+\tau}\right)\right]
$$

ここで、 $V_{t}^{D M M}$ はDDM による株式価值、 $d$ は配当性 向、また $\tau$ は当期末 $t$ からの経過期間を表している。な お、ここでは増資や減資等の資本取引は考慮しない。

評価時点 $t$ における株式価值を構成するのは、 $t$ 以降 における配当支払額であるが、その原資は利益である から、（7）式では利益の計算要素である収益および費 用の将来流列を確率変数とおいた上で、リスク中立確 率測度の下における期待值の割引現在価值として株 式価值が評価されている。

(7)式の DDM は、収益と費用の差額である利益の将 来流列を現在価值に割り引くという点で、いわゆる

「利益還元法」をベースとしており、これに既知の配 当性向が仮定された株式価值評価モデルということ になる ${ }^{10}$ 。

なお、(6)式のとおり当期末 $t$ の株主資本簿価の中に は、収益と費用の他にも資本 ${ }_{t}$ が含まれているが、こ れは配当の原資とはならないため、（7）式の DDM か らは除外されている。

ただし、DDM は継続企業を前提とする株式価值評 価モデルではあるものの、長期間にわたる配当額を推 定することは困難であり、通常は有限の評価期間が設 定される。この場合、推定期間の最終時点以降におけ る株式価值の増分をターミナルバリューして与える 必要がある。すなわち、当初の資本 ルバリューの一要素として、企業清算時における残余 財産に含まれることになる。

2 節では、負債満期時おける残余財産請求権のオプ ション価值という視点からRAOモデルが得られたが、 株主には他にも毎期の利益に対する利益配当請求権

10 なお、利益還元法と配当割引モデルおよび本稿の RC モ デルとの関係性について、文末の付録 A1 で検討している。 11 このような利益から控除される株主資本コストを、資本 が生み出す正常な利益と考えれば、残余利益とは正常利益を 上回る超過利益とみなされる。これにより残余利益とは、会 計上の「のれん」の価值を説明する理論的根拠とされている (Edwards and Bell [1961])。
が与えられている。この請求権とは、配当の原資とな る利益が稼得されることを条件として支払われる条 件付き請求権という意味でオプション価值を有して いる。したがって、このような配当金の支払額に基づ く配当割引モデルもまた、リアルオプションモデルと いうことになる。

ただし、配当割引モデルにおいて、経営者の配当政 策に依存する配当性向を、客観的な方法で予測ないし 特定することは困難である。そこで、次にこのような 配当性向に関する問題点が回避された残余利益モデ ルについて検討する。

\section{2 残余利益オプションモデル}

前述の配当割引モデルにおける配当性向の問題は、 利益から株主資本コストを控除して得られる残余利 益をベースとする「残余利益モデル(Residual Income Model: RIM)」によって回避される ${ }^{11}$ 。

そこで、以下ではRIM の導出過程に依拠しながら、 RIM に備わるリアルオプションとしての性質につい て考察する。そこで、まず次式のようなクリーンサー プラス条件が成立していると仮定する12。

$$
\text { 資本 }_{t+1}=\text { 資本 }_{t}+\text { 利益 }_{t+1}-\text { 配当 }_{t+1}
$$

ここで、株主資本コスト率を $r_{E}$ として、株主資本コス 卜 $r_{E}$ 資本 ${ }_{t}$ を(8)式の右辺に加減した上で配当額を求め、 これを配当割引モデルに代入すると、次式の残余利益 モデルが求められる13。

$$
V_{t}^{R I M}=\text { 資本 }_{t}+\sum_{\tau=1}^{\infty} \frac{\text { 利益 }_{t+\tau}-r_{E} \text { 資本 }_{t+\tau-1}}{\left(1+r_{E}\right)^{\tau}}
$$

(9)式のとおり、RIM による株式価值とは、時点 $t$ の 資本に $t$ 以降における残余利益の現在価值を加算して いくことによって求められることになる。

そこで任意の時点 $T$ における資本を、図表 3 のよう な正方形で表すと、この資本に加算される利益（線） から株主資本コストを差し引くことにより残余利益

(線) が求められる。この結果、縦軸の切片に RIM に よる株式価值 $V_{T+1}$ が与えられる。

ここで、 $t+1$ 以降の利益を確率変数とおくと、リス

12 クリーンサープラス会計とは、収益取引および費用取引 が(5)式および(6)式にしたがって、すべて損益計算書を経由 して貸借対照表の資本増分に計上される会計記録システム である。これに対して、例えば金融資産の時価評価損益等が 資本直入されるような会計処理が容認されている場合、これ はダーティーサープラス会計と呼ばれる。

13 付録 A2 に(9)式の RIM の導出過程が記されている。 


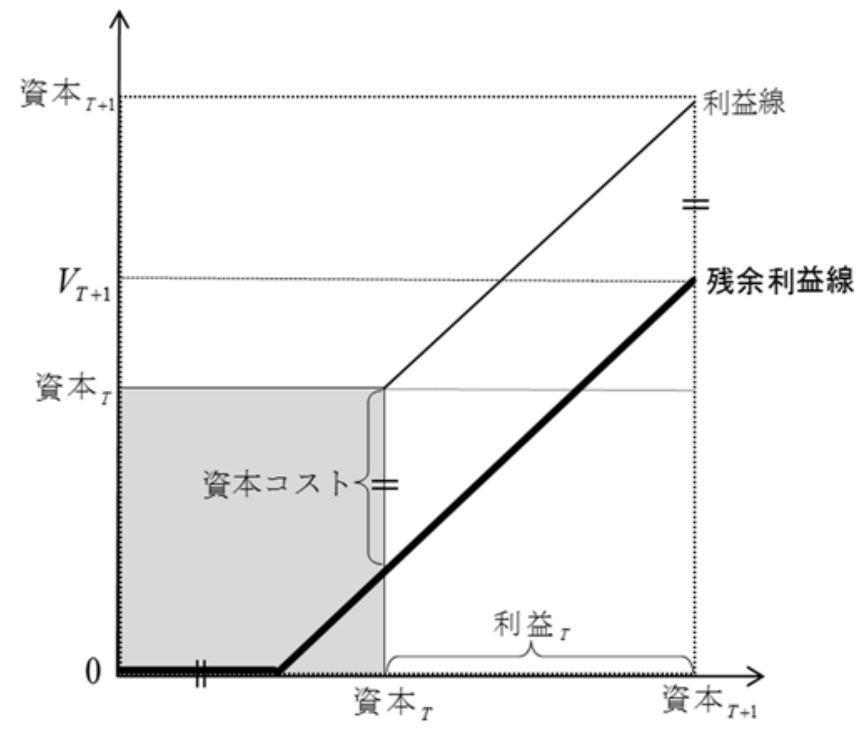

図表 3 残余利益と株式価値

ク中立確率測度の下で、RIM は次式のように表される。

$V_{t}^{R I M}=$ 資本 $_{t}+\left(\sum_{\tau=1}^{\infty} \frac{1}{\left(1+r_{F}\right)^{\tau}} E_{t}^{Q}\left[\right.\right.$ 利益 $_{t+\tau}-r_{F}$ 資本 $\left.\left._{t+\tau-1}^{\sim}\right]\right)$

さらに時点 $T$ 以降における残余利益の流列を $T V$ で 与えることにより、株式価值評価モデルとして次式の ようなリアルオプションモデルが得られる14。

$$
\begin{aligned}
& V_{t}^{R I O}=\operatorname{Max}\left\{\text { 資本 }_{t}\right. \\
& \left.+\left(\sum_{\tau=1}^{T} \frac{1}{\left(1+r_{F}\right)^{\tau}} E_{t}^{Q}\left[\text { 利益 }_{t+\tau}-r_{F} \text { 資本 }_{t+\tau-1}^{\sim}\right]\right)+E_{t}^{Q}[T V], 0\right\}
\end{aligned}
$$

このオプションは, 毎期の利益を状態変数とし,「期 末資本十残余利益の割引現在価值の総和の期待值 $(T V$ を含む)」を原資産、行使価格をゼロとするコールオプ ションと解される。そこで、この(11)式を「残余利益才 プションモデル（Residual Income Option Model: RIO モ デル)」と呼ぶこととする ${ }^{15}$ 。ただし、TVは時点 $t$ まで 割り引かれたターミナルバリューである。

142 節の RAO モデルでは、負債の満期時を株式価值の評 価時点としたが、RIO モデルは負債に依存しない資本変動モ デルであり、任意の時点 $T$ を評価時点とすれば、 $T$ 以降の価 值としての TVを外生的に与えなければならない。

15 (11)式の残余利益オプションモデルは、2015 年度 JAROS 研究発表大会 (国際大学) で、佐藤・大谷(2015) として報告 した株式価值評価モデルである。

16 オプションベースの株式価值評価モデルは、Burgstahler and Dichev (1997)、また非線形の残余利益モデルは、Biddle et. al., (2001)等によって提案されている。ただし、それらは本稿
Ohlson(1995)は、残余利益が 2 変数（残余利益とそ の他の情報）の自己回帰モデルに従うと仮定すること により、RIM を線形回帰モデルとして再構築した

(Linear Information Dynamics, LID と呼ばれている)。

これに対し本稿の RIO モデルとは、RIM を非線形 のリアルオプションモデルに拡張したところに特徵 があると考えられる16。

\section{Schwartz and Moon(2000)のオプションモデル}

Schwartz and Moon (2000)は、米国のインターネット 企業の株式価值をモンテカルロ・シミュレーションに よって評価することを目的とするリアルオプション モデルを提示した（以下、S\&M モデルと略称する）。

S\&M モデルでは、(7)式の DDM と同じように期間 損益計算で得られる利益を株式価值の源泉とするが、 利益としてはEBITDA（利子、税金および減価償却費 等控除前利益）を用いるとともに、この EBITDA が現 金の代理変数として次期以降に繰越され、全額が無リ スク金利で運用されると仮定されている。

すなわち S\&M モデルとは、期首の現金有高を初期 值として、これに(7)式の期間損益計算を「収益一費用 $=\Delta$ 現金」と変形した上で、毎期の現金累計額をもつ て株式価值とする評価モデルである。

その上で、この現金有高がゼロになった時点で企業 は倒産し、同時点における残余財産が株主に分配され ると仮定することにより、負数のペイオフが生じない コールオプションとして企業価值が評価される ${ }^{17}$ 。

すなわち、評価期間のターミナル時点 $T$ における現 金有高の推定值と同時点の EBITDA から得られるタ ーミナルバリューの合計額について、リスク中立確率 測度の下で期待值がとられ、その現在価值としての企 業価值 $F V_{t}$ が、次式のように求められる18。

$$
F V_{t}=e^{-r_{F}(T-t)} E_{t}^{Q}\left[\left\{\text { 現金 }_{T}+M\left(\text { 収益 }_{T}-\text { 費用 }_{T}\right)\right\}\right]
$$

ここで、FV $F$ は時点 $t$ における企業価值（総資本）で ある。また右辺の現金 $T$ は、 $t \sim T$ 期間において EBITDA が全額内部留保され安全利子率で運用されて得られ た現金有高を示している。

さらに(12)式右辺の $M$ は任意の乗数であり、 $M$ (収益 $_{T}-$ 費用 $_{T}$ ) は時点 $T$ における EBITDA を $M$ 倍

のように株主（投資家）の視点ではなく、経営者の投資政策 という視点から企業価值モデルが提示されている。

17 森平(2015)では、負のペイオフを記述することができる 確率過程モデルの詳細について、歴史的かつ理論的に考察さ れている。

18 (12)式は Schwartz and Moon (2000)の改良型モデルとして、 Schwartz and Moon (2001)で示されたリアルオプションモデ ルである。 
した值がターミナルバリューとして与えられること を示している。ただし費用については、収益に比例し て発生する変動費とそれ以外の固定費に分解され、そ の上で変動費と収益の比率 (変動費率 $v$ ) を定数と仮 定し、 $\mathrm{EBITDA}=(1-v)$ 収益 - 固定費というように、 EBITDA は収益の1次式で与えられる。つまり S\&M モデルでは、収益のみが確率変数とされている。

前述のとおり、EBITDA の全額が現金の増分として 内部留保され、 $d$ 現金 ${ }_{t}=$ 利益 $_{t} d t$ という関係が成立す ると仮定される。なお、繰越欠損金がない場合には法 人税の支払額だけ現金の内部留保額は減少する。

以上の S\&M モデルで評価されるのは総資本として の企業価值であるから、推定された企業価值から評価 時点における負債総額を控除した值が、株式価值を示 すことになる19。

本稿では、この S\&M モデルと 3.2 節の RIO モデル によって株式価值評価のシミュレーションを行い、両 モデルの評価精度について比較する。すなわち前掲の (6)式のとおり、S\&M モデルの状態変数である収益と は、資本変動の増加要因を総額（グロス）で表す会計 数值であるのに対して、RIOモデルにおける利益とは、 この収益から費用が差し引かれた資本変動の純額（ネ ット）情報であるから、両モデルにおけるリスクの源 泉は相違する。したがって、このようなリスクが株式 価值に及ぼす影響力について比較検討することが、次 節での検討課題となる。

\section{5. モンテカルロ・シミュレーション \\ 5.1 確率過程モデルと離散化式}

前節の Schwartz and Moon(2000)で分析されたのは、 インターネットビジネスを牽引する米国企業の株式 価值であるが、彼等の問題意識とは、当時の過熱した 株式市況（後にネットバブルと呼ばれる株価高騰）の 実態を解明するために、インターネットビジネスの中 核を占める企業の株式価值を、リアルオプションをべ ースとするシミュレーションによって評価すること で、その不確実性や脆弱性を検証することにあった。 一方、本稿で取り上げる $\mathrm{R}$ 社もまた、日本のインタ 一ネット市場において急速な成長を果たした企業の 一つであることから、まず S\&M モデルによる株式価 值評価を実行し、その上で RIO モデルの結果と比較検 討することとした。

まず $\mathrm{S} \& \mathrm{M}$ モデルの最大の特徵は、状態変数である 収益が幾何ブラウン運動に従い、かつ収益の期待成長 率はこの収益とは独立の平均回帰過程に従うと仮定 されているところにある。これは急成長するインター ネット企業といえども、当初の高い収益性が永続する ことはなく、いずれ市場の平均的趨勢に収束するとい

19 Schwartz and Moon (2000)では、負債および資本の構成要 素に応じて負債と資本を分離しているが、その処理は相当に
う想定によるものである。

図表 4 には、シミュレーション期間における $\mathrm{R}$ 社の

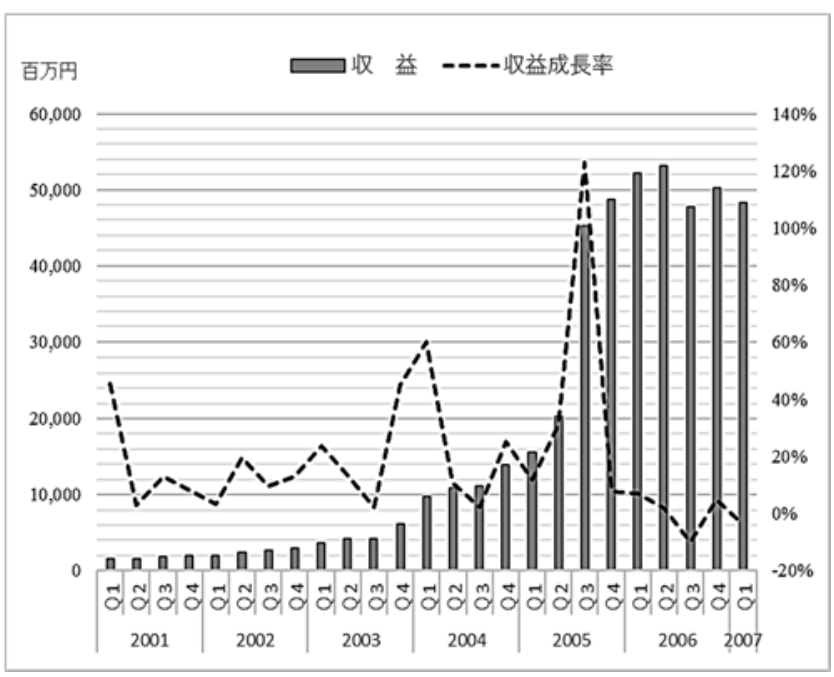

図表 $4 \quad \mathrm{R}$ 社の収益および収益の成長率

収益ならびに収益成長率が示されているが、ここでは $\mathrm{S} \& \mathrm{M}$ モデルの状態変数である収益に仮定された状況 と同様の傾向が観察される。その一方、 $\mathrm{R}$ 社は創業間 もなくして企業買収を開始し、これを繰り返しながら 多様な事業展開を推し進めたために、需要の変動に起 因するビジネスリスクはもとより、企業買収にともな う多額の資金調達に伴う財務リスクにも晒されてき た。

図表 5 には、同社の純資産額と負債比率が示されて いるが、当初は負債比率の急増による財務リスクが拡 大していたが、後半には純資産の増加にともない同リ スクは減少に転じている。

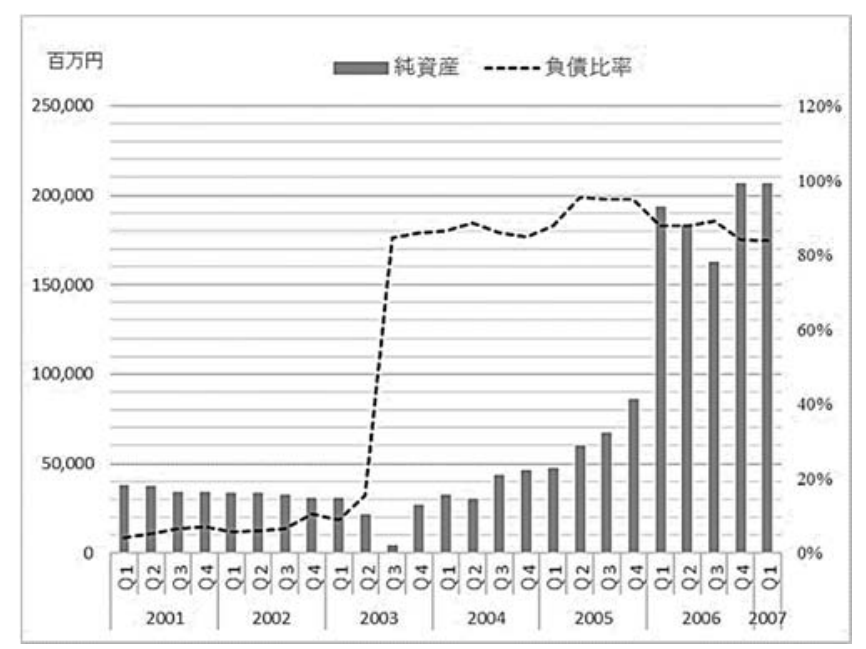

図表 5 R 社の純資産および負債比率

以上のように、事業リスクに加え大きな財務リスク にも晒された同社の株式価值を評価するには、S\&M

煩雑であるため、本稿では負債総額を用いた。 
モデルのような収益を状態変数とする評価モデルよ りも、事業活動のパフォーマンスを示す利益ならびに 資金調達コストとしての株主資本コストが反映され た RIO モデルを用いることが有効だと考えられる。

この点を明らかにするために、本稿では S\&M モデ ルと RIO モデルの両方を用いて $\mathrm{R}$ 社の株式価值を評 価し、両モデルの評価精度について比較検討する。

はじめに両モデルの状態変数であるが、本稿では両 者とも $\mathrm{S} \& \mathrm{M}$ モデルで設定されたのと同じ確率過程な らびに時系列に従うものと仮定する。ただし、以下で は両モデルを代表して、RIO モデルの状態変数である 利益に関する確率過程と時系列に関する諸仮定、およ びそれらの離散化式を示しておく。

RIO モデルの原資産は「期末資本十残余利益の割引 現在価值の総和の期待值（TV を含む）」であり、その 権利行使価格はゼロである。なお確率変動する状態変 数としての利益は、 $d$ 資本 ${ }_{t}=$ 利益 ${ }_{t} d t$ で与えられる。 ここで、利益の期待成長率を $\mu_{t}$ 、またそのボラティリ ティを $\sigma_{t}$ とおき、次式のような確率過程を設定する。

$$
\frac{d \text { 利益 }_{t}}{\text { 利益 }_{t}}=\mu_{t} d t+\sigma_{t} d z_{1}
$$

さらに利益の期待成長率 $\mu_{t}$ が、次式のような長期の期 待成長率 $\bar{\mu}$ をつ平均回帰過程に従うと仮定する。

$$
d \mu_{t}=\kappa\left(\bar{\mu}-\mu_{t}\right) d t+\eta_{t} d z_{2}
$$

ここで、 $\kappa$ は平均回帰係数であり利益の長期平均から

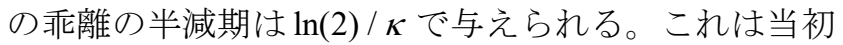
は大きな利益成長率を示すインターネット企業でも、 いずれ業種に応じた持続可能な利益成長率に確率的 に収束するという仮定によるものである。なお、(13) 式と(14)式の $d z_{1}$ と $d z_{2}$ はウィーナ一過程の増分を表す が、本稿では両者を無相関と仮定する。

さらに(13)式の利益のボラティリティ $\sigma_{t}$ は、次式の ように時間の変動とともに長期平均 $\bar{\sigma}$ と収束すると 仮定する。

$$
d \sigma_{t}=\kappa_{1}\left(\bar{\sigma}-\sigma_{t}\right) d t
$$

また(14)式の利益の期待成長率のボラティリティ $\eta_{t}$ については、時間の経過とともに次式のようにゼロに 収束すると仮定する。

$$
d \eta_{t}=-\kappa_{2} \eta_{t} d t
$$

以上の確率モデルには、利益および利益の期待成長 率のそれぞれ対して不確実性が仮定されている。した がって、これらの状態変数に対するリスク中立化のプ

20 Schwartz and Moon (2000)で示された(20)式には誤謬(typo) があったが、この点は Schwartz and Moon (2001)で修正され
ロセスとして、次のような測度変換を行う。

$$
\begin{gathered}
\frac{d \text { 利益 }_{t}}{\text { 利益 }_{t}}=\left(\mu_{t}-\lambda_{1} \sigma_{t}\right) d t+\sigma_{t} d z_{1}^{*} \\
d \mu_{t}=\left[\kappa\left(\bar{\mu}-\mu_{t}\right)-\lambda_{2} \eta_{t}\right] d t+\eta_{t} d z_{2}^{*}
\end{gathered}
$$

ここで、 $\lambda_{1}$ および $\lambda_{2}$ は利益および利益の期待成長率 に係るリスクの市場価格である。

以上のような連続時間の確率過程モデルおよび時 系列モデルに基づいて、モンテカルロ・シミュレーシ ヨンに必要となる利益および利益の期待成長率 $\mu_{t}$ 、ま た両者のボラティリティである $\sigma_{t}$ と $\eta_{t}$ に関する離散 化式は、それぞれ次式のように与えられる20。

$$
\begin{aligned}
& \text { 利益 }_{t+\Delta t}=\text { 利益 }_{t} e^{\left\{\left[\mu_{t}-\lambda_{1} \sigma_{t}-\left(\sigma_{t}^{2} / 2\right)_{1}\right] \Delta t+\sigma_{t} \sqrt{\Delta t} \varepsilon_{1}\right\}} \\
& \mu_{t+\Delta t}=\mu_{t} e^{-\kappa \Delta t}+\bar{\mu}\left(1-e^{-\kappa \Delta t}\right)+\eta_{t} \varepsilon_{2} \sqrt{\frac{1-e^{-2 \kappa \Delta t}}{2 \kappa}} \\
& \sigma_{t}=\sigma_{0} e^{-\kappa_{1} t}+\bar{\sigma}\left(1-e^{-\kappa_{1} t}\right)
\end{aligned}
$$$$
\eta_{t}=\eta_{0} e^{-\kappa_{2} t}
$$

既述のとおり、これらの確率過程および時系列モデ ルに関する離散化式は、S\&M モデルにおける状態変 数である収益に対して設定されたものと同様の仮定 に基づいている。これは $\mathrm{S} \& \mathrm{M}$ モデルと RIO モデルに よる株式価值の評価精度を、状態変数に設定される確 率過程や時系列の性質ではなく、両モデルの計算構造 上の相違に帰着させるための措置である。しかしなが ら、㛜密には両モデルの状態変数ごとに理論的に適切 な確率過程が設定されるべきところである。

\section{2 タイムラインとパラメータの設定}

シミュレーションのタイムラインは、次のとおりで ある。株式価值の評価時点は、2001 年第 3 四半期末お よび 2013 年第 4 四半期末の 2 時点とする。前者は R 社の収益（売上高）が、上場以来 3 年で約 30 倍と急 成長するとともに、大規模な企業買収のために多額の 資金調達が繰り返されるなど、市場環境ならびに資金 調達の内外両面における高い不確実性に直面してい た時期に当たる。これに対して第 2 の評価時点は、創 業期における不確実性が徐々に低減し、収益性ならび に資金調達の両面で安定期に入ったと見られる時期 である。

モンテカルロ・シミュレーションの推定期間は、四 半期を一つのタイムステップとして、その 25 年分で ある 100 期間とし、各期間におけるシミュレーション

ている。本稿の(20)式は修正後の離散化式である。 
の試行回数は 100 万回とする。

また図表 7 には、S\&M モデルおよび RIO モデルの 変数とパラメータ、ならびにデータソースと推定方法 が示されている。ただし、両モデルの状態変数に対し て同じ確率過程が設定されているため、両者に共通の パラメータについては、同一の記号で表されている。 なお、これらのパラメータは、会計情報、市場情報、 外部情報および推定情報の4つのカテゴリーに分類す ることができる。会計情報とは、それぞれの状態変数 の初期值、成長率およびボラティリティからなり、こ れらは財務諸表から入手可能である。本稿では、各評 価時点およびその直近の 3 期間の決算短信からこれら の情報を入手した。

また市場情報とは、状態変数の長期成長率ならびに 長期ボラティリティ等からなる市場の長期的傾向を 表すデータである。なお、S\&M モデルにおける収益 の長期成長率は経済産業省サービス動態統計室資料 をもとに推計した。ただし、RIO モデルにおける利益 に関する長期成長率および長期ボラティリティに関 する情報は得られなかったため、やむを得ず収益と同 じ值を用いた。また無リスク金利は、評価時点ごとに 直近 5 年分の 10 年物日本国債の金利の平均值を用い た。

さらに分析者による推定作業を必要とする推定情 報については、Schwartz and Moon (2000)ではアナリス 卜による予想值等が用いられているが、本稿では同様 の情報が得られなかったため、Schwartz and Moon (2000)の数值をそのまま採用した。この点についても 解消されるべき検討課題である。

最後にターミナルバリューTV は、シミュレーショ ンの最終期間 $T$ における EBITDA ならびに残余利益 の 10 倍とする ${ }^{21}$ 。

\section{3 シミュレーションの実行結果と感度分析}

図表 6 の上段(A)が、前半の 2001 年第 3 四半期末、 また下段(B)が、後半の 2013 年第 4 四半期末における シミュレーションの結果である。

ここで、シミュレーションによる株式評価額を時価 総額で除した比率を評価精度と定義すると、いずれの 時点においても、RIO モデルの方が $\mathrm{S} \& \mathrm{M}$ モデルより も時価総額に近似する評価額を産夕出している。すな わち、時価総額を基準とした場合、RIO モデルよりも $\mathrm{S} \& \mathrm{M}$ モデルの方が、株式価值を過小ないし過大評価 する傾向があるという結果になった ${ }^{22}$ 。

このような結果が生じたのは、S\&M モデルが資本 の増加要因を示す収益を状態変数とするフローモデ ルであるのに対して、RIO モデルは当初の株主資本簿

213.1 節で述べたように、理論的には TVの中には企業の清 算価值まで含まれるから、モデル毎に異なる值を付加するこ とは適切ではない。ただし、この点については企業の倒産価 值に基づくTVの推定法という視点から別稿で論じることと する。

22 残余利益モデルによる株式価值評価額は、事業投資によ って得られる評価額であり、現に保有されている金融投資
価に残余利益の現在価值が加算されるストックモデ ルであることが要因の一つになっていると考えられ る。ここでフロー情報とは、収益および費用のような 総額（グロス）情報を意味し、一方のストック情報と は、利益のように 2 時点間におけるフロー情報の差額 としての純額（ネット）情報を意味する。

既述のとおり、売上高などの収益は資本の増加要因 を示しており、それは資本の減少要因である費用が差 し引かれる前の総額情報である。このような収益は、 市場における需要変動などの外部環境に起因する不 確実性の影響を受けやすく、このことが収益の成長率 やボラティリティを通じて株式価值の評価額に大き く影響したものと考えられる。

さらに両モデルの状態変数である、収益および利益 それぞれの成長率とボラティリティは、 $\mathrm{R}$ 社の創業時 に近い 2001 年第 3 四半期末の方が、後半の 2013 年第 4 四半期末より大きく、創業時に近い方が不確実（不 安定）な経営環境にあったということができる。

しかしながら、図表 6 のとおり RIO モデルは、前半 が $3.3 \%$ また後半は $20.2 \%$ と両時点とも過小評価にな っている。すなわち、利益が安定している後半の方が 評価精度は低くなっているところに、同モデルの改善 の余地があると言うことができる。

これに対して、S\&M モデルでは前半がー9.8\%の過 小評価、また後半が $+49.3 \%$ の過大評価となっており、 RIO モデルとは異なり、過大・過小両方の評価額が得 られている。しかしながら、S\&M モデルでも後半の評 価時点では、状態変数である収益の面では安定期にあ るにも拘わらず、評価精度が低下している点には注意 が必要である。

(A) 評価時点；2001年第3四半期

\begin{tabular}{|c|c|c|c|c|}
\hline \multirow{2}{*}{ 株式価值評価モデル } & 資本 & 時価 & \multirow{2}{*}{ 評価額 } & \\
\hline & 簿価 & 総額 & & 精 度 \\
\hline RIOモデル & & & 153,237 & $97.7 \%$ \\
\hline & 36,980 & 156,850 & & \\
\hline S\&Mモデル & & & 141,521 & $90.2 \%$ \\
\hline
\end{tabular}

（B）評価時点；2013年第4四半期

\begin{tabular}{|c|c|c|c|c|}
\hline 株式価値評価モデル & $\begin{array}{l}\text { 資本 } \\
\text { 簿価 }\end{array}$ & $\begin{array}{l}\text { 時価 } \\
\text { 総額 }\end{array}$ & 評価額 & $\begin{array}{ll}\text { 評 価 } \\
\text { 精 }\end{array}$ \\
\hline RIOモデル & & & $1,652,585$ & $79.8 \%$ \\
\hline & 306,454 & $2,070,522$ & & \\
\hline 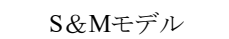 & & & $3,090,696$ & $149.3 \%$ \\
\hline
\end{tabular}

図表 6 シミュレーションの結果 （金額単位:百万円）

(現預金や投資有価証券からなり、その価值は時価の合計額 で把握できる)から得られる価值部分を含まないと考えるこ ともできる（桜井[2016] p.309）。このような金融投資として、 $\mathrm{R}$ 社の現金預金の現在有高を加味すれば、図表 6 の RIO モ デルによる株式価值の評価額は、2001 年が 156,062 百万円、 また 2013 年が 2,036,593 百万となる。 
以上の諸点について検討するため、図表 7 に示され たパラメータの感度分析の結果について検討する。こ こでの感度分析とは、2013 年第 4 四半期における各種 のパラメータを、それぞれ 5\%増加させた場合に生じ る株式評価額の変化率をいる。

図表 7 （B）の S \& $\mathrm{M}$ モデルにおいて、収益成長率の ボラティリティ初期值、および収益成長率の平均回帰 速度の 2 つパラメータが、株式価值に大きな変化を 生じさせていることが分かる $(+10.17 \%$ と - 10.20\%)。

このことは、S\&M モデルでは状態変数である収益 の期待成長率に係わるリスク、およびその期待成長率 の市場平均への回帰速度で示される、いわば市場にお ける需要動向といった企業の外部要因が、株式価值の 評価に大きく影響することを示唆している。したがっ
て、上述のように一見したところ安定期にあると思わ れる収益状況であっても、株式価值の評価額が過小・ 過大と大きく変動するという点で、S\&M モデルは株 式価值の評価精度上の不確実性が高い評価モデルと いうことができる。さらに、S\&M モデルでは EBITDA の推定にあたり、費用構造に関する分解分析が行われ たが、変動費と固定費の感応度 $(-7.37 \%$ と $-5.53 \%)$ の 方が、収益成長率の感応度 $(3.36 \%)$ よりも大きな值を 示している。このように企業内部の費用構造をモデル 化することは、ファンダメンタル分析における評価モ デルとしては優れているが、その反面、株式価值の評 価精度を高めるために費用構造等からなる内部情報 への十分なアクセスが要請されることにも留意する 必要がある。 
（A）RIOモデル

\begin{tabular}{|c|c|c|c|c|c|c|}
\hline 情報特性 & 確率変数およびパラメータ & 記号 & 2001年Q3 & 2013年Q4 & 度 $(+5 \%)$ & 情報源または推定法 \\
\hline \multirow{4}{*}{ 会計情報 } & 状態変数 $=$ 純利益 - 初期値 $=$ 期末資本 + 純利益 & - & 30,649 & 306,454 & - & \\
\hline & 利益成長率・初期值 & $\mu_{t}$ & $-7.67 \%$ & $4.00 \%$ & $1.33 \%$ & 直前3期平均値 \\
\hline & 利益ボラティリティ・初期值 & $\sigma_{t}$ & $11.26 \%$ & $6.50 \%$ & $0.02 \%$ & $"$ \\
\hline & 利益成長率ボラティリティ・初期値 & $\eta_{t}$ & $7.93 \%$ & $3.53 \%$ & $0.77 \%$ & $"$ \\
\hline \multirow{2}{*}{ 市場情報 } & 利益成長率・長期平均 & $\bar{\mu}$ & $-0.94 \%$ & $0.19 \%$ & $1.49 \%$ & 経産省サービス動態調查 \\
\hline & 利益ボラティリティ・長期平均 & $\bar{\sigma}$ & $2.14 \%$ & $0.82 \%$ & $-0.11 \%$ & $"$ \\
\hline 外部情報 & 無リスク金利 & $r_{F}$ & $1.69 \%$ & $1.09 \%$ & $-5.62 \%$ & 日本国債 10 年物平均 \\
\hline \multirow{5}{*}{ 推定情報 } & 利益成長率・平均回帰速度 & $\kappa$ & 0.08 & 0.17 & $-1.98 \%$ & Schwartz and Moon \\
\hline & 利益ボラティリティ・平均回帰速度 & $\kappa_{1}$ & 0.08 & 0.17 & $0.01 \%$ & $"$ \\
\hline & 利益成長率ボラティリティ・平均回帰速度 & $\kappa_{2}$ & 0.08 & 0.17 & $-0.39 \%$ & $"$ \\
\hline & 利益・リスクの市場価格 & $\lambda_{1}$ & 0.01 & 0.01 & $-0.04 \%$ & $"$ \\
\hline & 利益成長率・リスクの市場価格 & $\lambda_{2}$ & 0 & 0 & - & $"$ \\
\hline
\end{tabular}

（B） S\&Mモデル

\begin{tabular}{|c|c|c|c|c|c|c|}
\hline 情報特性 & 確率変数およびパラメータ & 記号 & 2001年Q3 & 2013年Q4 & 度 $(+5 \%)$ & 情報源または推定法 \\
\hline \multirow{7}{*}{ 会計情報 } & 状態変数 $=$ 収益. 初期值 & - & 1,770 & 148,843 & - & 四半期：百万円 \\
\hline & 期首現金残高 · 初期值 & - & 2,825 & 384,008 & - & \\
\hline & 収益成長率・初期值 & $\mu_{t}$ & $12.81 \%$ & $3.45 \%$ & $3.36 \%$ & 直前 3 期平均值 \\
\hline & 収益ボラティリティ・初期值 & $\sigma_{t}$ & $19.56 \%$ & $5.98 \%$ & $-0.17 \%$ & $"$ \\
\hline & 収益成長率ボラティリティ・初期伹 & $\eta_{t}$ & $2.06 \%$ & $7.00 \%$ & $10.17 \%$ & $"$ \\
\hline & 変動費率・初期值 & $v_{t}$ & $23.78 \%$ & $33.94 \%$ & $-7.37 \%$ & 費目別法による推定 \\
\hline & 固定費 & - & 824 & 71,879 & $-5.53 \%$ & $"$ \\
\hline \multirow{2}{*}{ 市場情報 } & 収益成長率 · 長期平均 & $\bar{\mu}$ & $-0.94 \%$ & $0.19 \%$ & $2.35 \%$ & 経産省サービス動態調査 \\
\hline & 収益ボラティリティ・長期平均 & $\bar{\sigma}$ & $2.14 \%$ & $0.82 \%$ & $-0.46 \%$ & $\prime \prime$ \\
\hline \multirow{2}{*}{ 外部情報 } & 法人税率 & $\operatorname{tax}$ & $40.00 \%$ & $36.00 \%$ & $-5.38 \%$ & 実効税率表 \\
\hline & 無リスク金利 & $r_{F}$ & $1.69 \%$ & $1.09 \%$ & $-0.97 \%$ & 日本国債 10 年物平均 \\
\hline \multirow{5}{*}{ 推定情報 } & 収益成長率 - 平均回帰速度 & $\kappa$ & 0.08 & 0.17 & $-10.20 \%$ & Schwartz and Moon \\
\hline & 収益ボラティリティ・平均回帰速度 & $\kappa_{1}$ & 0.08 & 0.17 & $1.22 \%$ & $"$ \\
\hline & 収益成長率ボラティリティ・平均回帰速度 & $\kappa_{2}$ & 0.08 & 0.17 & $-3.10 \%$ & $\prime$ \\
\hline & 収益・リスクの市場価格 & $\lambda_{1}$ & 0.01 & 0.01 & -0.46 & $\prime$ \\
\hline & 収益成長率・リスクの市場価格 & $\lambda_{2}$ & 0 & 0 & - & " \\
\hline
\end{tabular}

図表 7 シミュレーションのパラメータおよび感度分析の結果

一方の図表 7 (A) の RIO モデルでは、全体として パラメータの変動率である $5 \%$ を大きく超えるよう な株式価值の変動が生じることはなく、設定された パラメータには安定性があることが確認された。

具体的には、状態変数である利益の成長率は、前 半の-7.67\%から後半には $4.00 \%$ まで大きく回復した が、このことが必ずしも株式価值の感応度に大きな 影響を及ぼしているとは言えない、ということであ る $(1.33 \%)$ 。ただし、本稿の RIO モデルではターミ
ナル時点における残余利益の 10 期分を TVとしてカ ウントしているが、これは EBITDA をTV とする $\mathrm{S}$ \&M モデルよりも相当小さな $T V$ であり、このこと が同モデルの過小評価の一因になっているとも考え られる。

この他、RIO モデルに大きく影響するのが無リス ク金利であることも分かった $(-5.62 \%)$ 。のことは、 リスク中立確率測度を導出する際の測度変換プロセ スに関して慎重な対応が必要であることを示唆する 
結果である。

\section{6. 本稿の問題と今後の課題}

本稿では、株主からの委託財産に関する会計報告 責任としてのアカウンタビリティーという視点から、 株式に含まれるリアルオプション価值に基づく株式 価值評価モデルについて考察した。

まず 2 節では、Black and Scholes(1973)で示された 「残余財産オプションモデル」が、実物資産である 企業資産を原資産とするリアルオプションモデルと

して定式化されることを確認した。

その上で 3 節では、アカウンタビリティーを履行 するために必要となる期間損益計算に基づいて、株 主へのリターンという視点から配当割引モデルのリ アルオプション的性質について言及し、さらに配当 割引モデルから導出される残余利益モデルの計算構 造に着目して「残余利益オプションモデル（RIO モ デル)」を提案した。

残余利益モデルは、Ohlson(1995)によって線形情報 ダイナミクスモデル(LID)として拡張されて以来、利 益を説明変数とする線形回帰モデルの理論的根拠を 与える株式価值評価モデルとして位置づけられてき た。これに対して、本稿における RIO モデルは株式 に含まれるリアルオプション価值を推定する非線形 モデルとして独自の意義を有するものと考えられる。

そこで 4 節では、このような RIO モデルの比較対 象として Schwartz and Moon (2000)のモデル（S\&M モデル) を取り上げ、同モデルが「配当割引モデル」 に基づいた現金ベースのリアルオプションモデルで あることを確認した。

以上の検討をもとに、5 節では日本におけるイン ターネット企業の株式価值を、RIO モデルおよび $\mathrm{S}$ \&M モデルを用いて評価した。シミュレーションの 結果、時価総額を基準として両モデルの評価精度を 比較すると、RIO モデルの方が S\&M モデルよりも 評価上の差異率が小さくなるという結果が得られた。 このような結果が得られたのは、S\&M モデルの 場合、インターネット市場における需要変動に起因 する大きな不確実性に晒される収益を状態変数とす るため、収益に関するパラメータの設定次第で株式 価值の評価額が大きく変動するのに対して、RIO モ デルの場合、残余利益の算出段階で収益から費用お よび株主資本コストが控除されるため、S\&M モデ ルのような不確実性が減殺されパラメータの安定性 が確保されるからだと考えられる。

一方、モンテカルロ・シミュレーションに基づく 感度分析からも明らかなように、各種のパラメータ が株式価值の評価額に正負・大小の影響を与えるた め、これらパラメータの決定方法や推定方法につい ては、さらなる検討と改善が必要であることは明ら かである。

そもそも収益と利益という異なる会計数值を状態 変数とする 2 つの評価モデルを比較するためには、 状態変数ごとの性質が反映された適切なパラメータ
が設定されるべきところである。それにも拘わらず、 本稿では主として S\&M モデルを踏襲したシミュレ ーションに終始していることは、今後に残された大 きな課題である。

さらに、本稿ではインターネット企業 1 社の株式 価值が評価されたに過ぎない。したがって、RIO モ デルの評価精度をより精確に検証するためには、さ らに多くの事例、あるいはアーカイバルデータを用 いた計量的手法に拠る株式価值評価を行うことが必 要である。

\section{参考文献}

1. Biddle, G., P.Chen and G. Zhang (2001). When capital follows profitability: Non-linear residual income dynamics. Review of Accouniting Studies 6: 229-265.

2. Burgstahler, D.C. and I. Dichev (1997). Earnings, adaptation and equity value. The Accounting Review 72: 187-215.

3. Black, F. and M, Scholes. (1973). The pricing of options and corporate liabilities. Journal of Political Economy, 81, 637-659.

4. Merton, R. C. (1974). On the pricing of corporate debt: the risk structure of interest rates, Journal of Finance, 29, 449-470.

5. Edwards, E. and P. Bell. (1961). The Theory of Measurement of Business Income. Cambridge University Press.

6. Ohlson, J. A. (1995). Earnings, Book Values, and Dividends in Equity Valuation. Contemporary Accounting Research, 11(2): 661-687.

7. Schwartz, E. S. and M. Moon. (2000). Rational Pricing of Internet Companies. Financial Analyst Journal, 56, 62-75.

8. Schwartz, E. S. and M. Moon. (2001). Rational Pricing of Internet Companies Revisited. The Financial Review, 36, 7-25.

9. 大野薰(2013). 『モンテカルロ法によるリアルオ プション分析一事業計画の戦略的評価』。きん ざい.

10. 桜井久勝(2016).『財務諸表分析〔第 6 版〕』. 中央経済社.

11. 佐藤清和・大谷毅(2015). 「残余利益で推定する 株式のリアルオプション価值.」.『日本リアルオ プション学会 2015 年度研究報告大会予稿集』。

12. 佐藤靖・佐藤清和(2000).『キャッシュ・フロー 情報ーブームの異現象を超えて』。同文舘出版.

13. 杉本典之(1991). 『会計理論の探求一会計情報シ ステムへの記号論的接近』。同文舘出版.

14. 中岡英隆 (2016).「不適切会計に摇れる東芝のウ エスチングハウス買収戦略に関する一考察」。 『日本リアルオプション学会機関紙』. 第 8 巻 第 1 号.30-36.

15. 森平爽一郎 (2009).『信用リスクモデリングー測 定と管理』。朝倉書店.

16. 森平爽一郎 (2015).「オプション価格決定モデ 
ル : その学説史的展望(1) バシェリエ(1990)モデ ル」、『日本リアルオプション学会機関紙』。第 7 巻第 3 号.22-31.

\section{謝 辞}

お二人の匿名のレフェリーより、株式価值評価モ デルならびにシミュレーションに関する改善点につ いて多くのご教示をいただいた。ここに記して深謝 申し上げる。また Schwartz and Moon (2000)に関する モンテカルロ法は、大野(2013)掲載の乱数ジェネレ 一タおよび VBA プログラムを利用して実行された ものであるが、本稿の分析内容と結果のすべては筆 者の責に帰すものである。大野薰先生には、同プロ グラムの利用についてご快諾いただいことを感謝申 し上げる。なお、本研究は JSPS 科研費 $15 \mathrm{~K} 03767$ の 助成を受けたものである。

\section{付 録}

\section{A1. 利益還元法と配当割引モデル 23}

利益還元法とは、将来利益の流列の現在価值をも って株式価值とする評価方法であり、これに配当性 向を乗ずれば配当割引モデルが得られる。しかしな がら、利益還元法では内部留保された利益の再投資 の効果が明示的には考慮されない。この点について 検討するため、まず利益と配当支払額の差額が、翌 期の事業に再投資されると仮定する。すなわち、配 当性向を $d$ とおけば、利益 - 配当 $=$ 利益 $\times(1-d)$ と いう関係が成り立つ。

このようにして再投資された事業の期待収益率を $r_{S}$ とすると、利益 $\times\left\{1+(1-d) r_{S}\right\}$ が翌期の利益とな る。ここで、利益が毎期一定の成長率 $G$ で成長して いるとすると、 $(1-d) r_{S}=G$ となる。そこで、この $r_{S}$ が株式の期待収益率 $r_{E}$ と等しいと仮定することに より、次式の関係が得られる。

$$
r_{E}-G=r_{E} d
$$

一方、配当割引モデルにおいて、配当支払額の成 長率が利益の成長率 $G$ に一致するとすれば、株式価 值は、配当 $/\left(r_{E}-G\right)$ で与えられることから、次のよ うな関係式が導かれる。

$$
\frac{\text { 配当 }}{r_{E}-G}=\frac{\text { 利益 } d}{r_{E} d}=\frac{\text { 利益 }}{r_{E}}
$$

ここで、左辺は配当の成長率 $G$ が仮定された配当 割引モデルであり、右辺は利益還元法による株式価

23 配当割引モデルと収益費用オプションモデルとの整合 性に関する(23)式および(24)式の記述は、匿名のレフェリ
值評価モデルである。このように内部留保利益の再 投資の効果が織り込まれた利益還元法と配当成長が 織り込まれた、配当割引モデルの同一性が示される ことになる。

\section{A2. 残余利益モデルの導出}

ここでは、(9)式の残余利益モデルが導かれること を示す。本文(8)式で示されたクリーンサープラス関 係式、資本 ${ }_{t+1}=$ 資本 $_{t}+$ 利益 $_{t+1}-$ 配当 $_{t+1}$ の右辺に $+\left(r_{E}\right.$ 資本 $_{t}-r_{E}$ 資本 $\left._{t}\right)$ と株主資本コストを加減する項 を加えてから、 $t=0 、 t=1 、 t=2 \cdots$ の各期の 配当 $t_{t}$ を抽出 した上で、これを配当割引モデルに代入する。

これより配当割引モデルによる株式価值 $V_{t}^{D D M}$ は、 次式のように表される24。

$$
\begin{aligned}
V_{t}^{D D M} & =\frac{\left(1+r_{e}\right) \text { 資本 }_{0}+\text { 利益 }_{1}-r_{e} \text { 資本 }_{0}-\text { 資本 }_{1}}{1+r_{e}} \\
& +\frac{\left(1+r_{e}\right) \text { 資本 }_{1}+\text { 利益 }_{2}-r_{e} \text { 資本 }_{1}-\text { 資本 }_{2}}{\left(1+r_{e}\right)^{2}} \\
& +\frac{\left(1+r_{e}\right) \text { 資本 }_{2}+\text { 利益 }_{3}-r_{e} \text { 資本 }_{2}-\text { 資本 }_{3}}{\left(1+r_{e}\right)^{3}}+\cdots
\end{aligned}
$$

ここで、 $t \rightarrow \infty$ のとき、資本 $t /\left(1+r_{e}\right)^{\tau} \rightarrow 0$ と仮定す れば、時点 $t$ における株式価值の評価額は、本文(9) 式の残余利益モデル $V_{t}^{R I M}$ が与えられる。

なお、本文 5 節のような RIM によるシミュレーシ ヨンを実行する場合には、シミュレーションの試行 期間における最終時点を $T$ とした場合、 $t \rightarrow T$ のと きに資本 $t /\left(1+r_{e}\right)^{T} \rightarrow 0$ と仮定することはできない。 そこで、時点 $T$ 以降の株式価值として何らかのター ミナルバリューTVを設定することが必要となる。

一からのご教示に基づくものである。

24 RIM の導出は、桜井(2016)第 13 章に拠るものである。 